\title{
Collision of the Mocha fracture zone and a $<4$ Ma old wave of orogenic uplift in the Andes $\left(36^{\circ}-38^{\circ} \mathrm{S}\right)$
}

\author{
Andrés Folguera' and Victor A. Ramos ${ }^{1}$ \\ 'LABORATORIO DE TECTÓNICA ANDINA, UNIVERSIDAD DE BUENOS AIRES, CONSEJO NACIONAL DE INVESTIGACIONES CIENTÍFICAS Y TÉCNICAS (CONICET), CP C1033AAJ BUENOS \\ AIRES, ARGENTINA
}

\section{ABSTRACT}

The southern Central and northern Patagonian Andes $\left(34^{\circ}-45^{\circ} \mathrm{S}\right)$ are characterized by low to no crustal seismicity at the retroarc fold and thrust belt, in contrast to the Pampean flat subduction zone located immediately to the north $\left(27^{\circ}-33^{\circ} 30^{\prime} \mathrm{S}\right)$. Detailed examination of this area shows no indication of contractional neotectonics with the exception of the segment located between $36^{\circ}$ and $38^{\circ} \mathrm{S}$. There, out-of-sequence transpressional deformation, initially developed in the 1.7-1.4 Ma interval, affects the western retroarc between $36^{\circ}$ and $38^{\circ} \mathrm{S}$ next to the arc zone. It is between these latitudes that contractional deformation $<3.6 \mathrm{Ma}$ old developed in the forearc region. Oblique collision of the Mocha fracture zone and its associated rise explains the distribution, extent, and timing of <3.6 Ma contractional deformations from the forearc to the foreland, as well as incipient shallowing of the Nazca plate beneath the South American plate, which has been inferred from seismic, gravimetric, and arc dynamics studies.

\section{INTRODUCTION}

As a general paradigm it is broadly accepted that the Andes are formed by the subduction of a series of oceanic plates beneath the South American plate. The southern Central and northern Patagonian Andes are formed in an area of collision of the Nazca and South American plates. The Nazca plate is at present formed at the Chilean mid-ocean ridge, segmented by a series of NE transform faults that at the site of subduction produces strong gradients in oceanic floor age (Fig. 1). These transform faults are associated with important bathymetric anomalies that have been described recently as isostatically anomalous buoyant settings produced by highly serpentinized crust (Contreras Reyes, 2008). The South American margin between $38^{\circ}$ and $40^{\circ} \mathrm{S}$ is the locus of subduction of a plateau $<4000 \mathrm{~m}$ below sea level, herein named the Mocha rise, which is crossed at its mid sector by the Mocha fracture zone (Fig. 1). The Andean retroarc between $34^{\circ}$ and $45^{\circ} \mathrm{S}$, compared to the Andes north of $33^{\circ} 30^{\prime} \mathrm{S}$, is characterized by scarce intracrustal seismicity. Most of the retroarc fold and thrust belt at these latitudes lacks shallow seismicity as well as neotectonic indicators of contractional activity $<3 \mathrm{Ma}$, being restricted to both the arc zone next to the Argentinian-Chilean boundary and the coastal zone (Bohm et al., 2002) (Fig. 2). In the arc zone over the eastern Andean slope the Antiñir-Copahue fault system is an active thrust system developed between $36^{\circ}$ and $38^{\circ} \mathrm{S}$ (Folguera et al., 2004) (Fig. 3), affecting the Cretaceous to Miocene fold and thrust belt in the hinterland area (Folguera et al., 2006). Subcrustal seismicity occurs mainly in the Wadatti-Benioff zone at these latitudes (Bohm et al., 2002), indicating a roughly $30^{\circ}$ east-dipping zone beneath the South American plate. However, two independent lines of evidence have refined this picture in the past few years, showing some additional complexity. On the one hand, three seismic refraction profiles crossing the forearc and arc zones have shown that the subduction angle at $37^{\circ} \mathrm{S}$ is dipping up to $6.5^{\circ}$ shallower than to the north and south of this latitude (Krawczyk et al., 2006). In addition, this observation is compatible with a longwavelength gravity anomaly of up to $80 \mathrm{mGal}$ observed between $36^{\circ}$ and $38^{\circ} \mathrm{S}$ that characterizes the coastal zone (Fig. 2). This anomaly has been modeled after a shallower geometry of the subducted oceanic (Nazca) plate beneath the South American plate (Tašárová, 2004; Hackney et al., 2006), as shown in the seismic surveys. This "shallowing" of the subducted Nazca plate beneath the South American plate could be a transient feature as inferred from arc dynamics in the past 3-4 Ma. Early Pliocene arc-related associations (Vergara and Muñoz, 1982) have been mapped extensively in this Andean segment. South of $38^{\circ} 15^{\prime} \mathrm{S}$, their westernmost extent coincides spatially with the location of 2 Ma younger modern volcanoes associated with the arc front (Stern, 2004), while to the north they are systematically displaced, with the youngest arc chain $40-50 \mathrm{~km}$ east of the early Pliocene arc (Fig. 2). This implies an eastward redefinition of the asthenospheric wedge, the site of arc-related magma production during the past 3-4 Ma, coincident with the shallower subducted Nazca plate zone inferred from seismic and gravimetric studies. This paper explores the relationship of a colliding fracture zone with flat slab subduction and its deformational and magmatic effects on the overriding plate. Even though the influence of subducted aseismic ridges on the determination of shallow subduction zones (Nur and Ben-Avraham, 1981; Pilger, 1981; Gutscher et al., 2000; among others) had been discussed, no such relation had been proposed for the case of subduction of serpentinized, thus highly buoyant, transform fracture zones. Therefore, a new tectonic model is provided for the $36^{\circ}-38^{\circ} \mathrm{S}$ Andean segment, explaining $<4$ Ma old arc dynamics and orogenic construction. Detailed connections between deformation of the overriding plate and a flattened slab have not been described in many places. The Andean subduction zone between $36^{\circ}$ and $38^{\circ} \mathrm{S}$ has the potential to provide a better understanding of the kinematic and dynamic connection between shallow subduction and deformation of the overriding plate globally, which is the main thrust of this contribution.

\section{LESS THAN 4 Ma OLD DEFORMATIONS INTHE ANDES BETWEEN $36^{\circ}$ AND $40^{\circ} \mathrm{S}$}

Less than 4 Ma old deformations in the Main Andes between $36^{\circ}$ and $40^{\circ} \mathrm{S}$ are governed by 


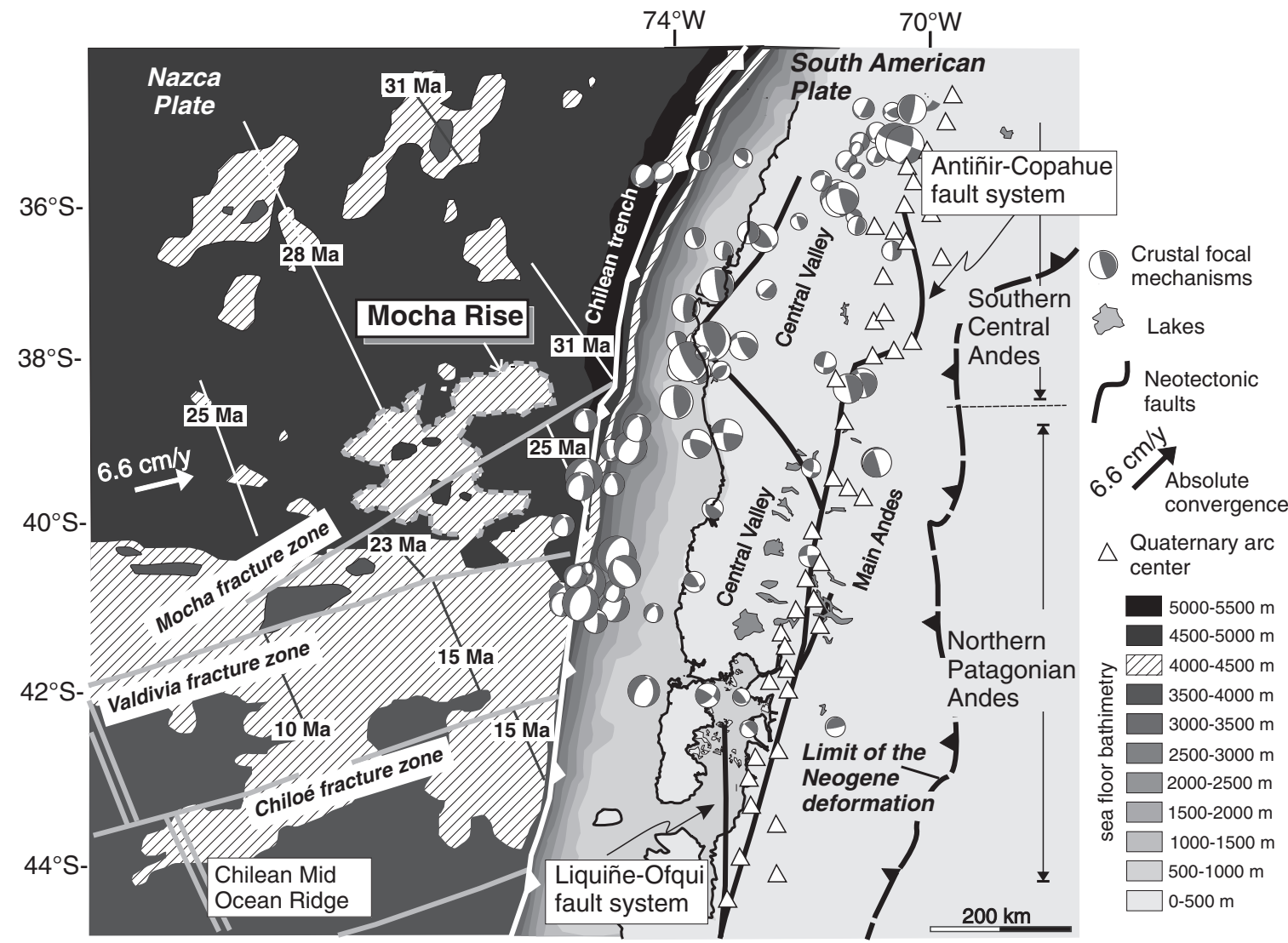

Figure 1. Southern Central and northern Patagonian Andes formed by the subduction of the Nazca plate beneath the South American plate. Note the highly variable bathymetry at the Chilean trench and the high seismicity at the point where the Mocha fracture zone meets the trench. Numbers in segments parallel to the Chilean mid-ocean ridge indicate the age of the ocean floor in millions of years. Seismicity has been taken from Harvard CMT catalog (http://www.globalcmt.org/ CMTsearch.html).

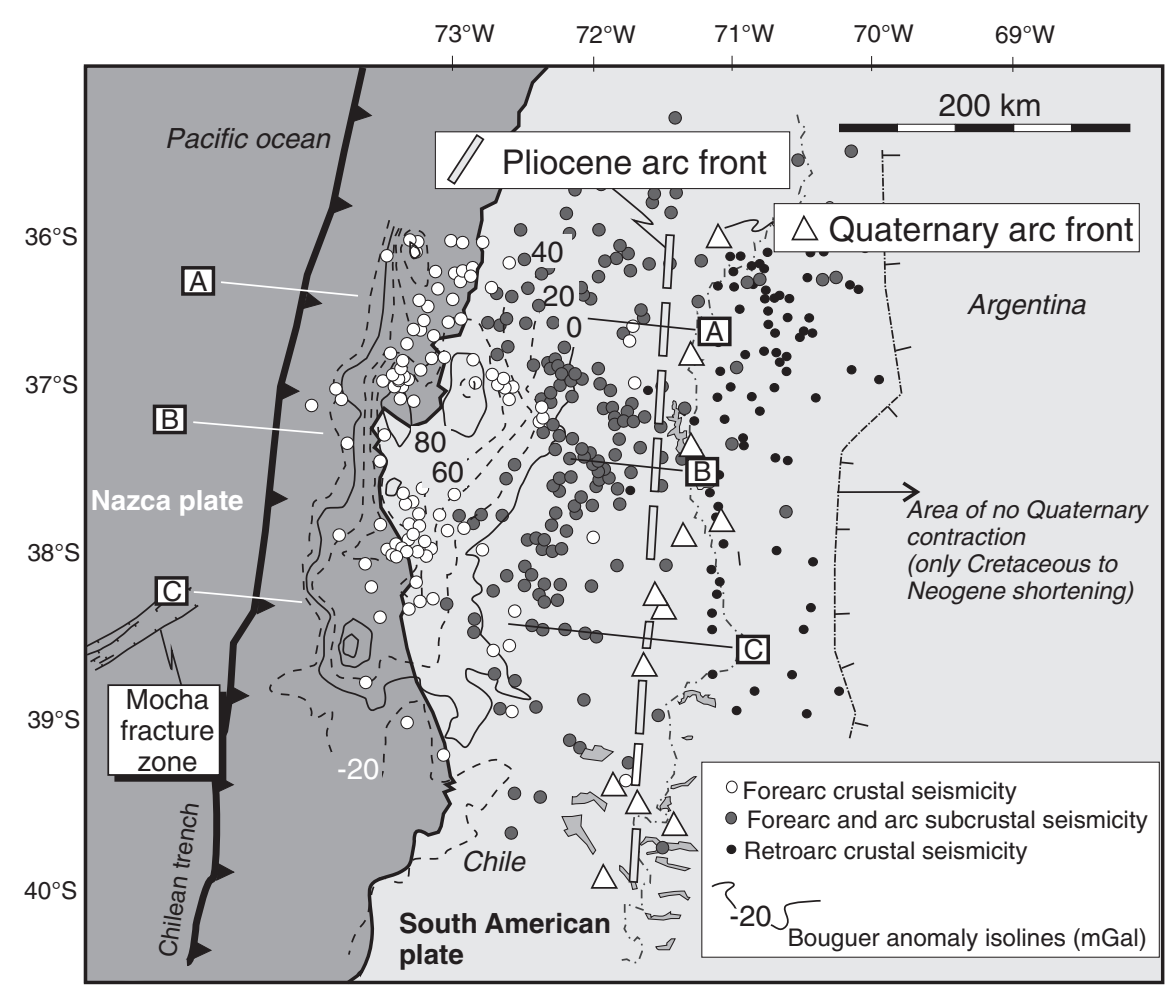

Figure 2. Subduction of the Nazca plate beneath the South American plate at $35^{\circ}-40^{\circ} \mathrm{S}$ and associated seismicity and gravity. A, B, and C indicate positions of seismic refraction profiles (Krawczyk et al., 2006) at the forearc zone, which indicate a $6^{\circ}-7^{\circ}$ shallower subduction angle at $B$ with respect to neighboring surveys. Onshore positive and long wavelength gravity anomalies between $36^{\circ}$ and $38^{\circ} \mathrm{S}$ have been ascribed to the effect of the oceanic Nazca plate at depth: 3D density models (Tašárová, 2004; Hackney et al., 2006) corroborate a shallower subduction angle at B. Note that Pliocene and Quaternary arc fronts, coincident south of $38^{\circ} 15^{\prime} \mathrm{S}$, are separated for $40-50 \mathrm{~km}$ north of this latitude in coincidence with the inferred segment of shallower forearc subduction. 


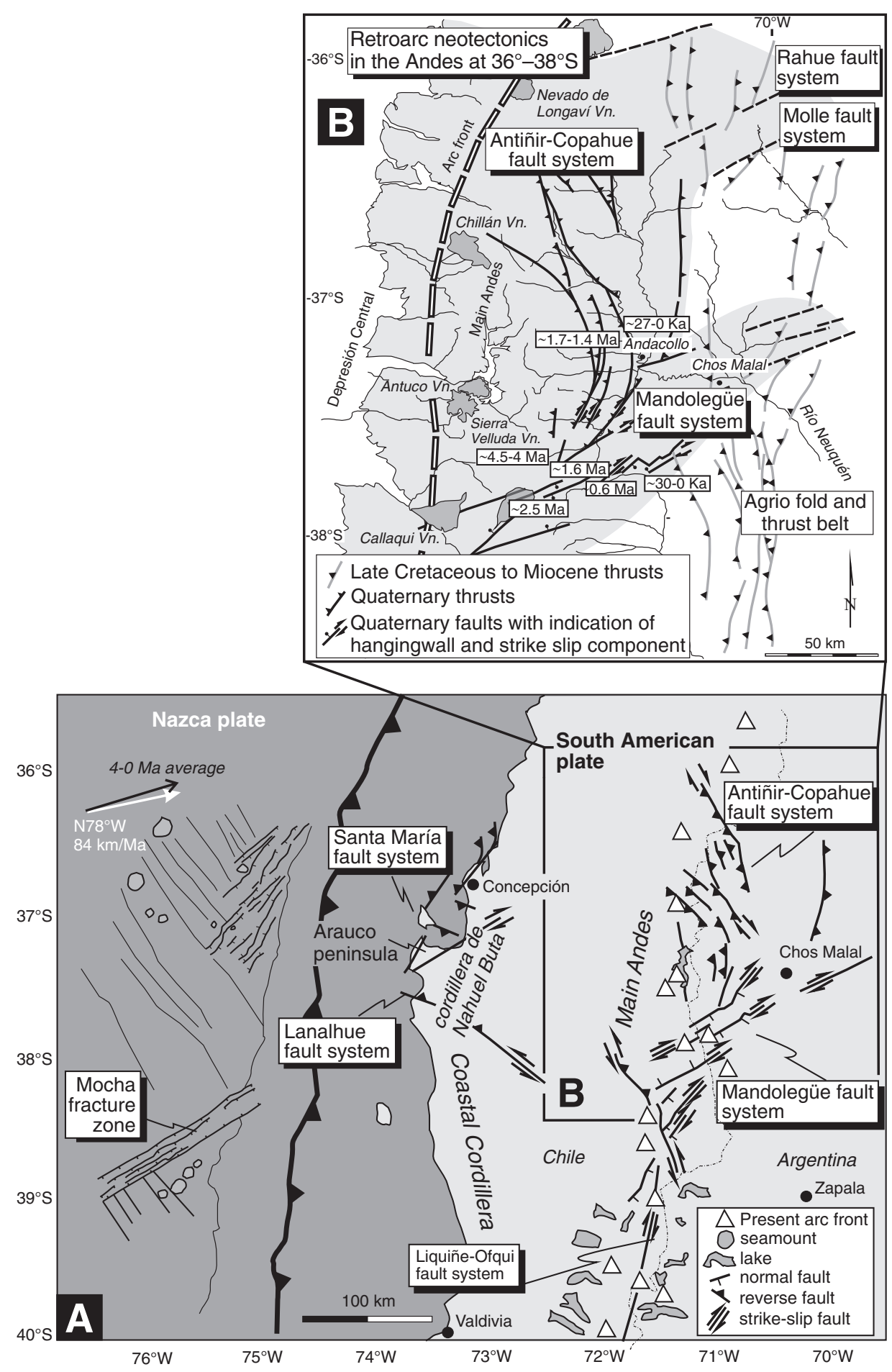

Figure 3. (A) Less than $3.6 \mathrm{Ma}$ old deformation through the Andean arc and forearc between $36^{\circ}$ and $40^{\circ} \mathrm{S}$ (from Folguera et al., 2004, 2006; Melnick et al., 2006; Rosenau et al., 2006). The average relative convergence between the Nazca and South American plates in the past $4 \mathrm{Ma}$ is from Cande and Kent (1992). Ocean floor features from Scherwath et al. (2006) and Contreras-Reyes (2008). (B) The Andean Quaternary orogenic front between $36^{\circ}$ and $38^{\circ} \mathrm{S}$ corresponding to the Antiñir-Copahue fault system. Gray area indicates Quaternary deformation superimposed on the Cretaceous to Miocene fold and thrust belt. Ages in rectangles indicate temporal constraints in deformation (see text for further description). four distinctive fault systems (Figs. 3 and 4). (1) South of $38^{\circ} 30^{\prime} \mathrm{S}$, beyond the scope of this study, the intra-arc NNE Liquiñe-Ofqui fault system (Fig. 3) has been described as a dextral strike-slip fault zone from seismic and kinematic points of view (Lavenu and Cembrano, 1999; Rosenau et al., 2006). (2) To the north, between $37^{\circ} 30^{\prime}$ and $38^{\circ} 30^{\prime} \mathrm{S}$, this scheme passes into a series of NE- to ENE-trending dextral transtensional faults grouped in the Mandolegüe fault system (Figs. 3 and 4). These faults are associated with pull-apart depocenters diachronously formed between $5 \mathrm{Ma}$ and $2.5 \mathrm{Ma}$ at the arc zone (Melnick et al., 2006b), and between 1.5 and $0.6 \mathrm{Ma}$ at the western retroarc zone, and even younger than $100 \mathrm{ka}$ at the foreland zone (Fig. 3) (Folguera et al., 2004). This fault system tectonically affects a fold and thrust belt active at 97-10 Ma, as determined by fissiontrack data, intrusive crosscutting relationships, and synorogenic strata (Zamora Valcarce et al., 2009). (3) Between $36^{\circ}$ and $37^{\circ} 30^{\prime} \mathrm{S}$, a series of $\mathrm{N}$ to $\mathrm{NW}$ dextral transpressional faults, grouped in the Antiñir-Copahue fault system (Fig. 3), initially accommodated shortening between 1.7 and 1.4 Ma, the ages of pre- and post-contractional volcanic products in the area, respectively (Folguera et al., 2004, 2006). This system still accommodates shortening at the eastern side of the Andes, based on tectonic scarps displacing soils. (4) Immediately to the north, between $36^{\circ}$ and $36^{\circ} 30^{\prime} \mathrm{S}$, a series of NE-trending fault systems controlled Quaternary retroarc eruptions associated with graben and half-graben structures, such as the Rahue and Molle fault systems that delimit the northern edge of the Antiñir-Copahue fault system (Fig. 3).

\section{LESS THAN 4 MA OLD SHORTENING AT THE COASTAL CORDILLERA BETWEEN $36^{\circ}$ AND $40^{\circ} \mathrm{S}$}

Neotectonic studies show that the Coastal Cordillera has been exhumed inhomogeneously by compressional structures between $36^{\circ}$ and $40^{\circ} \mathrm{S}$ (Fig. 3) (Melnick et al., 2006a). These studies are in accordance with fission-track analyses that identify the $37^{\circ}-38^{\circ} \mathrm{S}$ segment corresponding to the Arauco peninsula as being exhumed in the past 3-4 Ma, in contrast to the rest of the coastal zone, that was uplifted in Late Cretaceous times (Glodny et al., 2007). NW- and NEoriented structures have accommodated contraction in the past 3.6 Ma corresponding to the Isla Santa María and Lanalhue fault systems (Fig. 3), resulting in the tectonic inversion of Early Cretaceous to early Pliocene extensional depocenters (Melnick et al., 2006a). These structures were responsible for the uplift of Isla Santa María above sea level as well as for the anomalous high 
Area of collision of Mocha transform zone in the last $3.6 \mathrm{Ma}$

$37^{\circ} \mathrm{S}$

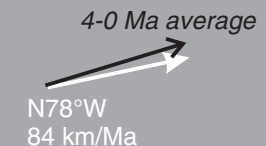

\section{Nazca plate}

$\mathrm{N} 78^{\circ} \mathrm{W}$

S

$40^{\circ} \mathrm{S}$

$39^{\circ} \mathrm{S}$

$6^{\circ} \mathrm{S}$

Extrapolated Mocha fracture zone 3.6 Ma ago

$38^{\circ} \mathrm{S}$

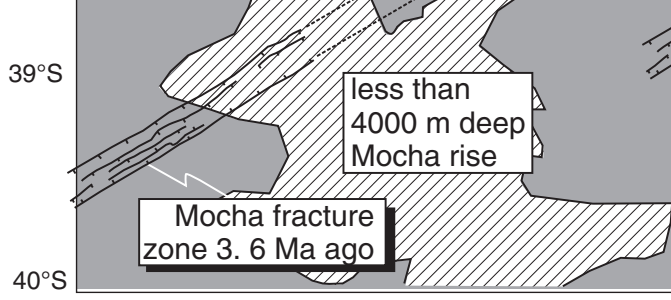

$76 \mathrm{~W}$

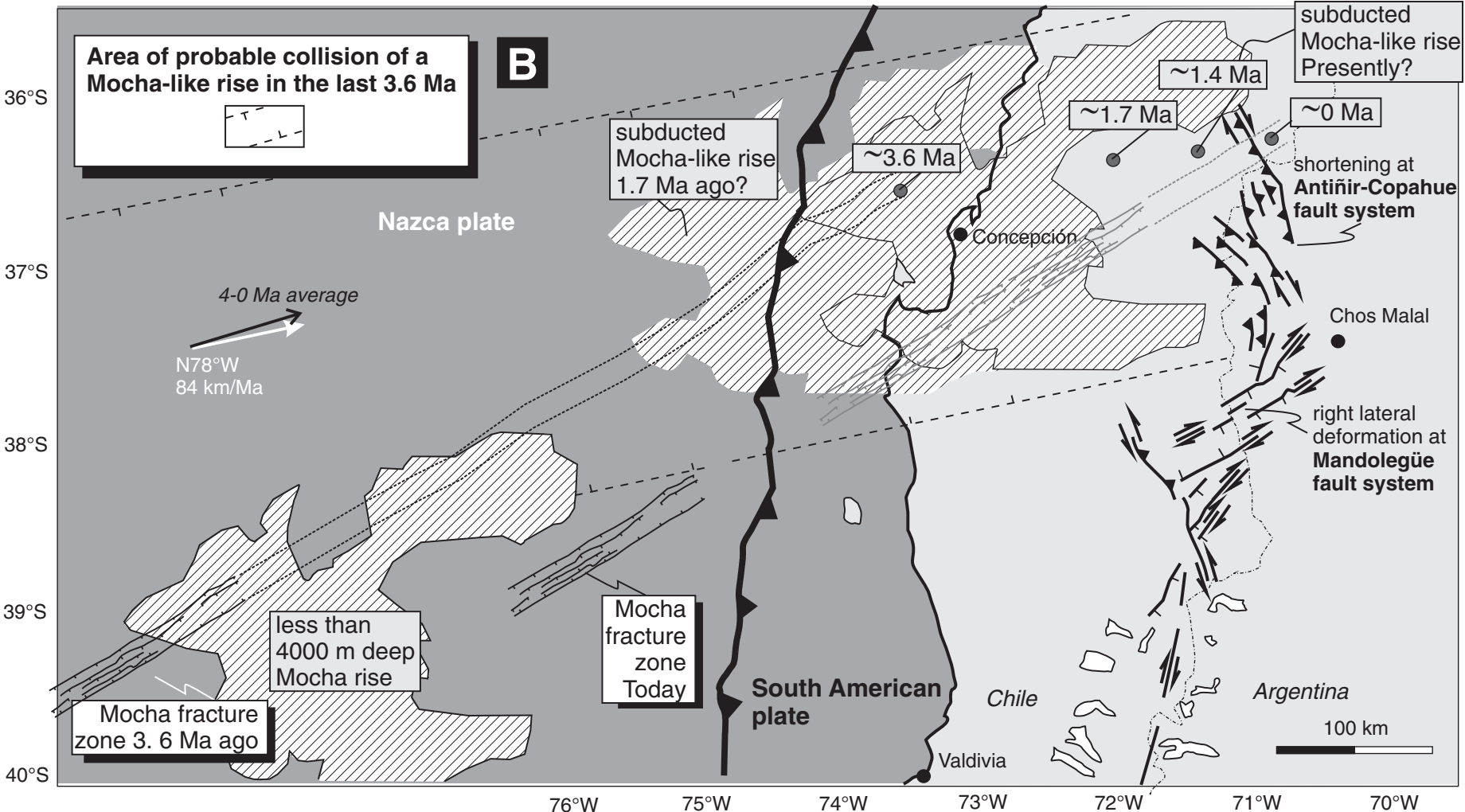

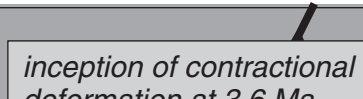
deformation at $3.6 \mathrm{Ma}$

Figure 4. (A) Location of subducted Mocha fracture zone beneath the Andes some $3.6 \mathrm{Ma}$ ago and today, and relation to $<3.6 \mathrm{Ma}$ old structure. Eastward progression of contractional deformation since 3.6 Ma in the forearc to 1.7-1.4 Ma in the retroarc zone coincides with the inferred displacement of Mocha fracture zone beneath the South American plate. Note that coastal exhumation determined from fission-track data at <3 Ma (Glodny et al., 2007) coincides with the area corresponding to the Mocha fracture zone interacting with the South American plate, and particularly with the area occupied by the inferred Mocha-like rise. (B) The inferred Mocha-like rise beneath the South American plate has a latitudinal extent compatible with the 200-km-long, out-of-sequence Antiñir-Copahue fault system. 


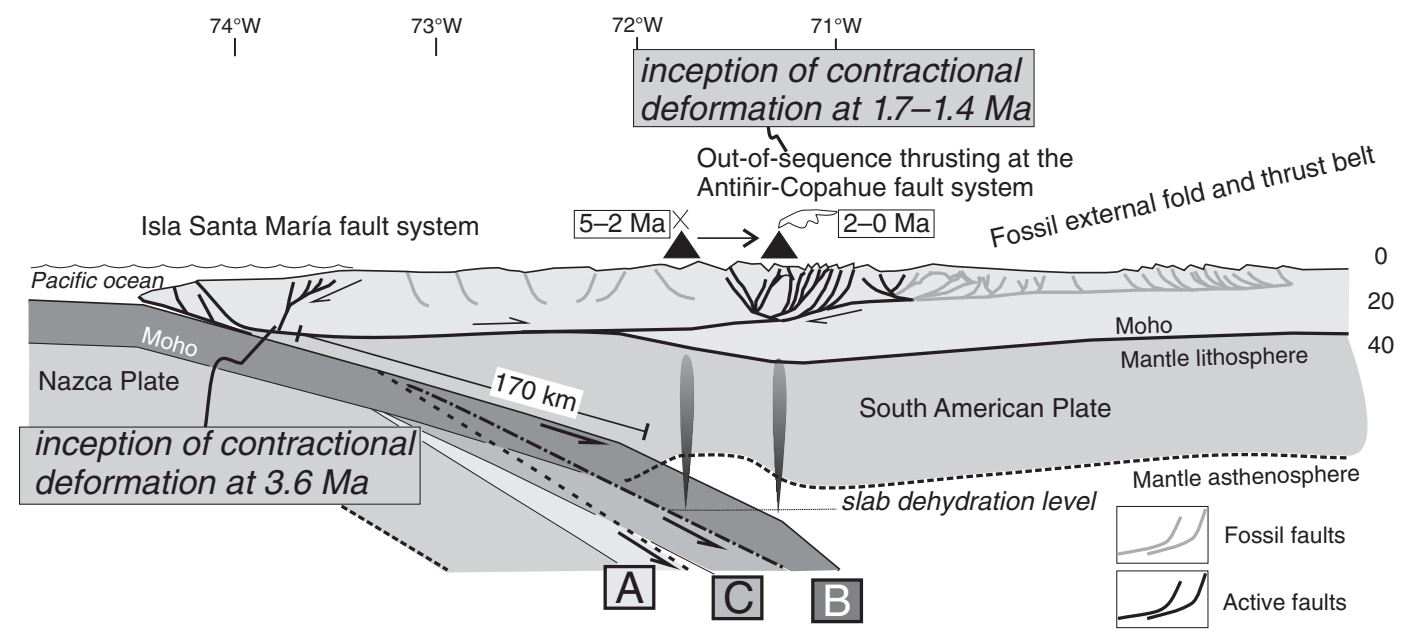

Figure 5. Cross section located at $37^{\circ} \mathrm{S}$, neotectonic deformation, and Wadatti-Benioff geometries for three adjacent segments determined from seismic refraction (Krawczyk et al., 2006) (see location in Fig. 2). Black triangles indicate positions of early Pliocene and Quaternary arc fronts, respectively. Retroarc neotectonic structure is from Folguera et al. $(2004,2006)$, and offshore neotectonic structure is from Melnick et al. (2006a).

relief of the cordillera de Nahuel Buta region between $37^{\circ}$ and $38^{\circ} \mathrm{S}$ (Fig. 3) (Melnick et al., 2006a; Glodny et al., 2007).

\section{COLLISION OF THE MOCHA FRACTURE ZONE WITH THE SOUTH AMERICAN MARGIN}

Relative convergence between the Nazca and South American plates in the past 4 Ma inferred from ocean magnetic anomalies (Fig. 3) (Cande and Kent, 1992) implies that 3.6-3 Ma ago, at the time of inception of contractional deformation at the Chilean coast between $37^{\circ}$ and $38^{\circ} \mathrm{S}$ (Melnick et al., 2006a; Glodny et al., 2007), the point of interaction between the Mocha fracture zone and the Chilean trench would have been located some $130 \mathrm{~km}$ north of its present position (Figs. 3 and 4). Extrapolating its trend from this 3.6 Ma position at the Chilean trench to the coastal zone, the meridian corresponding to the Lanalhue and Santa María fault systems, where contractional deformations started, would be reached at $\sim 36^{\circ} 30^{\prime} \mathrm{S}$ (Fig. 4A). Roughly two million years separate inception of contractional deformation at the Chilean coast from younger contractional deformations at the Antiñir-Copahue fault system in the retroarc area (Figs. 3 and 4). Therefore, the Mocha fracture zone and associated Mocha-like rise have been displaced beneath the South American continent some $280 \mathrm{~km}$ parallel to relative plate motion (corrected by the cosine of $\sim 22^{\circ}$, corresponding to the Nazca plate subduction angle at the site of its present collision with the Chilean trench) (Fig. 4B). This implies that the point along the fracture zone where the obstacle or asperity that initially produced deformation at the forearc zone is hosted would be located approximately at $36^{\circ} 20^{\prime} \mathrm{S}$, beneath the western retroarc area (Fig. 4). That is in accordance with highly hydrated magmas at those latitudes in the Quaternary Nevado de Longaví volcano, interpreted from anomalously high dehydration of the serpentinized Mocha fracture zone at the asthenospheric wedge (Sellés et al., 2004).

\section{DISCUSSION}

The Mocha fracture zone has been described as a highly serpentinized zone both from nearshore seismic studies and the nature of arcrelated magmas at the place where its trend reaches the arc front. Seismic refraction studies and gravity data show that subduction of the Nazca plate at the site of inferred subduction of a Mocha-like rise since $3.6 \mathrm{Ma}$ ago $\left(\sim 36^{\circ} 30^{\prime}-37^{\circ} 30^{\prime} \mathrm{S}\right)$ is on the order of $6^{\circ}$ shallower than in neighboring segments. This zone coincides with the development of $<3.6 \mathrm{Ma}$ contractional structures in the Coastal Cordillera and 1.7-1.4 Ma shortening at the arc and western retroarc areas. A $280 \mathrm{~km}$ distance separates both areas of young tectonic activity, coinciding accurately with the time necessary to subduct the point along the Mocha fracture zone that initially produced deformation at the forearc area, from beneath the coastal domain to the western retroarc zone. An oceanic "plateau" of similar dimensions to the one surrounding the present Mocha fracture zone could have been subducted beneath the South American plate, justifying the accurate latitudinal extent of this renewed wave of contractional deformations in the Andes. Considering that dehydration of the Nazca plate beneath the South American plate is now produced at the intersection between a vertical plane at the arc front and the Nazca plate itself, we can speculate that this depth has remained unique through recent time for the pressure and temperature conditions to generate arc magmas (Fig. 5). Subducted slab geometry at the latitudes of shallowing (B in Fig. 2) could be used for determination of the dehydration depth at $\sim 37^{\circ} \mathrm{S}$ as depicted in Figure 5. The line of intersection of this horizontal plane (magma production depth at $\sim 37^{\circ} \mathrm{S}$ ) with a slab of geometry determined beyond the area of subduction of the Mocha fracture zone in the past $3.6 \mathrm{Ma}$ (C in Fig. $2 ; \sim 38^{\circ} \mathrm{S}$ ) occurs just beneath the early Pliocene arc front (Fig. 5). This implies that shallowing of the Nazca plate at the site of Mocha-like rise subduction $\left(\sim 37^{\circ} \mathrm{S}\right)$ would have involved a steeper geometry close to that of its neighboring segments.

\section{ACKNOWLEDGMENTS}

The authors kindly acknowledge the reviewers' and Lithosphere Editor Raymond M Russo's suggestions and corrections.

\section{REFERENCES CITED}

Bohm, M., Lüth, S., Echtler, H., Asch, G., Bataille, K Bruhn, C., Rietbrock, A., and Wigger, P., 2002, The southern Andes between $36^{\circ}$ and $40^{\circ} \mathrm{S}$ latitude: Seismicity and average seismic velocities:Tectonophysics, v. 356, p. 275-289, doi: 10.1016/S0040-1951(02)00399-2.

Cande, S., and Kent, D., 1992, Revised calibration of the geomagnetic time scale for the Late Cretaceous and Cenozoic: Journal of Geophysical Research, v. 97, p. $13,917-13,951$.

Contreras-Reyes, E., 2008, Evolution of the seismic structure of the incoming/subducting oceanic Nazca plate off south-central Chile [Ph.D. thesis]: Kiel, Germany, Christian-Albrechts-Universität zu Kiel, 143 p.

Folguera, A., Ramos, V.A., Hermanns, R.L., and Naranjo, J., 2004, Neotectonics in the foothills of the southernmost central Andes $\left(37^{\circ} 38^{\circ} \mathrm{S}\right)$ : Evidence of strike-slip displacement along the Antiñir-Copahue fault zone: Tectonics, v. 23, TC5008, doi: 10.1029/2003TC001533.

Folguera, A., Ramos, V., González Díaz, E., and Hermanns, R., 2006, Miocene to Quaternary deformation of the Guañacos fold and thrust belt in the Neuquén Andes between $37^{\circ}$ and $37^{\circ} 30^{\prime}$ S, in Kay, S.M., and Ramos, V.A., eds., Evolution of an Andean Margin: A Tectonic and Magmatic View from the Andes to the Neuquén Basin $\left(35^{\circ}-39^{\circ} \mathrm{S}\right)$ : Geological Society of America Special Paper 407, p. 247-266. 
Glodny, J., Gräfe, K., Echtler, H., and Rosenau, M., 2007, Mesozoic to Quaternary continental margin dynamics in south-central Chile $\left(36^{\circ}-42^{\circ} \mathrm{S}\right)$ : The apatite and zircon fission track perspective: International Journal of Earth Sciences, doi: 10.1007/s00531007-0203-1.

Gutscher, M., Spakman, W., Biijward, H., and Engdahl, E., 2000, Geodynamic of flat subduction: Seismicity and tomographic constraints from the Andean margin:Tectonics, v. 19, p. 814-833, doi: 10.1029/1999TC001152.

Hackney, R., Echtler, H., Franz, G., Götze, H.-J., Lucassen, F., Marchenko, D., Melnick, D., Meyer, U., Schmidt, S., Tašárová, Z., Tassara, A., and Wienecke, S., 2006, The segmented overriding plate and coupling at the southcentral Chilean margin, in Oncken, G., et al., eds., The Andes-Active Subduction Orogeny: Berlin, Heidelberg, NewYork, Frontiers in Earth Sciences 1, Springer Verlag, p. 351-370.

Krawczyk, C., Mechie, J., Tašárová, Z., Lüth, S., Stiller, M. Brasse, H., Echtler, H.P., Bataille, K., Wigger, P., and Araneda, M., 2006, Geophysical signatures and active tectonics at the south-central Chilean margin, in Oncken, G., et al., eds., The Andes-Active Subduction Orogeny: Berlin, Heidelberg, New York, Frontiers in Earth Sciences 1, Springer Verlag, p. 171-192.

Lavenu, A., and Cembrano, J., 1999, Compressional and tranpressional stress pattern for Pliocene and Quaternary brittle deformation in fore arc and intra arc zones (Andes of central and southern Chile): Journal of Structural Geology, v. 21, p. 1669-1691, doi: 10.1016/ S0191-8141(99)00111-X

Melnick, D., Bookhagen, B., Echtler, H., and Strecker, M. 2006a, Coastal deformation and great subduction earthquakes, Isla Santa María, Chile ( $\left.37^{\circ} \mathrm{S}\right)$ : Geological Society of America Bulletin, v. 118, no. 11/12, p. 1463 1480, doi: 10.1130/B25865.1.

Melnick, D., Folguera, A., and Ramos, V., 2006b, Structural control on arc volcanism:The Caviahue-Copahue complex, Central to Patagonian Andes transition (38 ${ }^{\circ} \mathrm{S}$ ): Journal of South American Earth Sciences, v. 22, p. 66-88, doi: 10.1016/j.jsames.2006.08.008.

Nur, A., and Ben-Avraham, Z., 1981, Volcanic gaps and the consumption of aseismic ridges in South America, in Nazca plate, in Kulm, L.D., Dymond, J., Dasch, E.J., and Hussing, D.M., eds., Nazca Plate: Crustal Formation and Andean Convergence: Boulder, Geological Society of America Memoir 154, p. 729-740.

Pilger, R., 1981, Plate reconstructions, aseismic ridges, and low angle subduction beneath the Andes: Geological Society of America Bulletin, v. 92, p. 448-456, doi: 10.1130/0016-7606(1981)92<448:PRARAL>2.0.CO;2.

Rosenau, M., Melnick, D., and Echtler, H., 2006, Kinematic constraints on intra-arc shear and strain partitioning in the southern Andes between $38^{\circ}$ and $42^{\circ} \mathrm{S}$ latitude: Tectonics, v. 25, TC4013, doi: 10.1029/2005TC001943.

Scherwath, M., Flueh, E., Grevemeyer, I., Tilmann, F., Contreras-Reyes, E., and Weinrebe, W., 2006, Investigating subduction zone processes in Chile: Eos (Transactions, American Geophysical Union), v. 87, no. 27, doi: 10.1029/2006EO270001.

Sellés, D., Rodríguez, A., Dungan, M., Naranjo, J., and Gardeweg, M., 2004, Geochemistry of Nevado de Longaví volcano $\left(36.2^{\circ} \mathrm{S}\right)$ : A compositionally atypical arc volcano in the Southern Volcanic Zone of the Andes: Revista Geológica de Chile, v. 31, no. 2, p. 293-315.

Stern, C., 2004, Active Andean volcanism: Its geologic and tectonic setting: Revista Geológica de Chile, v. 31, no. 2 , p. 161-206.

Tašárová, Z., 2004, Gravity data analysis and interdisciplinary $3 \mathrm{D}$ modelling of a convergent plate margin (Chile, $36-42^{\circ}$ S) [Ph.D. thesis]: Berlin, Germany, Freie Univer sität Berlin, $187 \mathrm{p}$.

Vergara, M., and Muñoz, J., 1982, La Formación Cola de Zorro en la alta cordillera andina chilena $\left(36^{\circ}-39^{\circ} \mathrm{S}\right)$, sus características petrográficas y petrológicas: Una revisión: Revista Geológica de Chile, v. 17, p. 31-46.

Zamora Valcarce, G., Zapata, T., Ramos, V.A., Rodríguez, F. and Bernardo, L., 2009, Evolución tectónica del frente andino en Neuquén: Revista de la Asociación Geológica Argentina, v. 65, p. 150-160.

MANUSCRIPT RECEIVED 12 JUNE 2009 REVISED MANUSCRIPT RECEIVED 13 AUGUST 2009 MANUSCRIPT ACCEPTED 25 AUGUST 2009

Printed in the USA 